\title{
Tillage Reduces Yield and Crown, Fern, and Bud Growth in a Mature Asparagus Planting
}

\author{
Darlene Wilcox-Lee and Daniel T. Drost \\ Department of Fruit and Vegetable Science; Cornell University, Long Island Horticultural Research \\ Laboratory, 39 Sound Avenue, Riverhead, NY 11901
}

Additional index words. no-till, Asparagus officinalis, carbohydrates

\begin{abstract}
Asparagus officinalis L. CV. Centennial established with transplants in 1983 was maintained with tillage or a no-till (NT) system to evaluate effects of tillage on yield and plant growth in a mature asparagus planting. Metribuzin or metribuzin + napropamide at 1.12 and $1.68 \mathrm{~kg}$ a.i./ha, respectively, were used for weed control in both tillage regimes. Marketable yields were assessed for 5 years. In 1989, in addition to yield data, destructive harvests of entire plants were made every 3 weeks from March to November to evaluate the effect of tillage on fern, crown, and bud growth, and carbohydrate status. Yields were reduced by tillage from $12 \%$ to $50 \%$ from 1985 to 1989 . There were no herbicide effects nor was there an effect on yield due to an interaction between herbicides and tillage. All indices of growth measured for NT exceeded those in tilled plots, although seasonal patterns of growth were similar in both. Crown and fern weight, bud cluster, and bud and fern counts were higher by 178\%, 175\%, 152\%, 161\%, and 195\%, respectively, in NT than in tilled plots. The metribuzin + napropamide combination did not reduce fern fresh weight or yield, but significantly reduced the number of bud clusters, buds, and ferns when compared to metribuzin alone. Chemical names used: 4-amino-(1,1-dimethylethyl)-3-(methylthio)-l (metribuzin); 2,4-triazin-5(4H) -one, N,N-diethyl2-(naphthalenyloxy)-propanamide (napropamide).
\end{abstract}

Production practices for asparagus in the eastern United States have traditionally included an early spring tillage, often followed by a second tillage after harvest. In addition to providing weed control, tillage also softens crusted soil to facilitate spear emergence and incorporates the previous season's fern residue. Consequently, tillage has remained a common practice in asparagus production despite the development of effective herbicide programs and the better yields and weed control that have been obtained in NT than in tilled asparagus (Putnam, 1972). However, the long-term effects of tillage on asparagus growth and yield are not documented.

Although growth and carbohydrate partitioning in young asparagus plants have been described (Benson and Takatori, 1980; Dufault and Greig, 1983; Fisher, 1982; Haynes, 1987), no data are available on crown and bud growth in mature asparagus plantings. Further, there is. no information on the effect of tillage on crown, root, and bud development or carbohydrate levels in asparagus. Since tillage reduces yields in young asparagus plantings (Putnam, 1972), it is likely that it disrupts the underground storage and reproductive processes of the plant. The objectives of this study were to determine the long-term effect of tillage on asparagus yields and evaluate the effect of tillage on shoot, bud, and root growth, and carbohydrate levels of mature asparagus plants over an entire growing season.

\section{Materials and Methods}

Ten-week-old seedlings of 'Centennial' asparagus were planted in a furrow 20-cm deep on 5 June 1983. Root systems were covered with soil at the time of transplanting, but furrows were not completely refilled with soil. All plants were mechanically cultivated until mid-July 1983, when the soil surface was again level due to the movement of soil during cultivations. Plots were maintained in a flat culture thereafter. The soil was a Riverhead sandy loam (mixed, mesic Typic Dystrochept) with a $\mathrm{pH}$ of 6.2 and $2 \%$ organic matter. Fertilizer was broadcast and incorpo-

Received for publication 1 Oct. 1990. Paper no. 5, Dept. of Fruit and Vegetable Science, Cornell Univ. The cost of publishing this paper was defrayed in part by the payment of page charges. Under postal regulations, this paper therefore must be hereby marked advertisement solely to indicate this fact. rated before planting at $\left(\mathrm{kg} \cdot \mathrm{ha}^{-1}\right) 110 \mathrm{~N}-100 \mathrm{P}-90 \mathrm{~K}$. Additional fertilizer at $\left(\mathrm{kg} \cdot \mathrm{ha}^{-1}\right) 56 \mathrm{~N}-50 \mathrm{P}-45 \mathrm{~K}$ was applied before spear emergence in 1984 and in subsequent years immediately after harvest. Irrigation and pesticides were applied as required throughout the duration of the experiment. The experiment was arranged in a randomized complete block design with four replications. Each plot was a single row $9.1 \mathrm{~m}$ in length with 30 $\mathrm{cm}$ between plants in the row. Plots were $1.7 \mathrm{~m}$ apart, and a buffer plot was planted between treated plots. Blocks were separated by $6.1 \mathrm{~m}$ to facilitate access by field equipment.

Herbicide and tillage treatments were initiated in Apr. 1984 before spear emergence. 1,1 Dimethyl-4,4'-bipyridinium salts (paraquat) $\left(0.56 \mathrm{~kg} \cdot \mathrm{ha}^{-1}\right)$ was applied to kill existing vegetation before the application of the pre-emergence herbicides. The treatments were: 1) till + metribuzin, 2) till + metribuzin + napropamide, 3) NT + metribuzin, and 4) NT+ metribuzin + napropamide. Metribuzin was used at a rate of $1.12 \mathrm{~kg}$ a. i./ha and napropamide at $1.68 \mathrm{~kg}$ a.i./ha.

Ferns were left standing over the winter and mowed with a rotary mower each spring to a height of $\gg 8 \mathrm{~cm}$. In NT plots, plant debris was left on the soil surface, and herbicides were applied over the top of the debris. In tilled plots, ferns were mowed and then incorporated $8 \mathrm{~cm}$ into the soil with a rototiller (1.8 $\mathrm{m}$ wide) before the application of herbicides. Because of the weed pressure that occurred when mature plots were harvested for 8 weeks, pre-emergence herbicide treatments listed above were reapplied to all plots after harvest, and tilled plots received an additional postharvest tillage from 1987 to 1989.

Yield data, 1985 to 1988. In 1985 and 1986, plots were harvested three times weekly for 2 and 4 weeks, respectively. In 1987 and 1988, plots were harvested three times weekly for 8 weeks. Spears were cut at the soil surface and trimmed to 23 $\mathrm{cm}$ in length; yields were separated into large $(>1.58 \mathrm{~cm})$ and medium-sized ( $>0.95$ and $<1.58 \mathrm{~cm}$ in diameter at the cut end) categories. Yield data were subjected to a two-way analysis of variance, and the effects of tillage, herbicides, and a tillage $\times$ herbicide interaction were determined.

Abbreviation: NT, no till. 
Growth, yield, and carbohydrate content, 1989. Entire asparagus plants were sampled destructively at 3-week intervals to assess shoot and root growth during the growing season. Sampling began on 23 Mar. and ended on 9 Nov. (total of 12 sampling dates). Due to the small plot size $(9.1 \mathrm{~m})$, only six samples, each consisting of $1.5 \mathrm{~m}$ of row, could be obtained from each plot. Therefore, the treatment combinations till. and $\mathrm{NT}+$ metribuzin and till and NT + metribuzin + napropamide were sampled alternately at 3 -week intervals throughout the 7 months of sampling. Harvests were randomly assigned to either end of the sample rows over the course of the growing season.

To avoid damaging plants from which 1989 yield data were collected, yields were taken only from those plots assigned to the last three sampling dates because they would not be disturbed before completion of harvest. Spears were harvested three times weekly for 8 weeks as described earlier, except that the ends were trimmed from marketable spears and unmarketable culls were weighed in addition to marketable yields to better assess tillage effects on growth. On the appropriate sample days, all emerged spears or ferns were cut at soil level, counted, and fresh weights recorded. Samples were dug using a tractor-mounted U-blade that undercut the crown and helped to lift the roots. The blade was $55 \mathrm{~cm}$ wide and set to cut $45 \mathrm{~cm}$ deep. Asparagus roots and crowns were shaken free of soil before being washed thoroughly with water. Roots were allowed to air dry before their fresh weights and the number of bud clusters and buds were recorded. Random samples of fleshy storage roots were removed for later carbohydrate analysis.

Root samples were dried at 70C for $48 \mathrm{~h}$ before being ground in a Wiley mill. Ground storage roots $(1 \mathrm{~g})$ were homogenized with $100 \mathrm{ml}$ of distilled water for $1 \mathrm{~min}$ and filtered. Samples were diluted (1: 100) with distilled water and analyzed using anthrone reagent (Haynes, 1987; Shelton and Lacy, 1980) with a fructose standard. Optical density was measured at $620 \mathrm{~nm}$ with a Coleman model 620 spectrophotometer (Perkin Elmer, Coleman Instruments Div., Oak Brook, Ill.).

Statistical analyses were performed using SAS general linear model procedures (SAS, 1985). Data for the harvest dates, tillage systems, and herbicide combinations were combined and analysis of variance conducted to determine the main effects and interactions. The data was then reanalyzed for each harvest date to determine the individual effects of tillage and herbicides on growth over the season.

\section{Results}

Yield. There was no effect of herbicides nor was there an effect on yield due to an interaction between herbicides and tillage from 1985 to 1989 . Consequently, yield data are pooled and presented for till and NT treatments only. Yields were not significantly reduced by tillage the first year of harvest (1985) (Table 1); however, from 1986 to 1989, tillage significantly reduced both the total number and weight of marketable spears (Table 1).

In 1989, marketable and unmarketable yields, which included culls and the butt trimmings from marketable spears, were analyzed for early, mid-, and late-harvest periods. Both weight and number of large and medium-sized spears were significantly reduced by tillage in the early season harvests (Table 2). The yield of unmarketable spears was not affected by tillage early in the season. In the mid-season harvests, there was no significant effect of tillage on yield of large spears. Yields of mediumsized and unmarketable spears were significantly decreased by tillage in both the mid- and late-season harvests. Yields of large spears were not reduced by tillage in the late-season harvests. There was no difference in the total percentage of marketable spears between till and NT; however, the percentage of marketable weight was significantly reduced by tillage.

Growth and carbohydrates. Asparagus growth, as indicated by crown, fern, and bud growth, was significantly affected by tillage, herbicide, and harvest dates in 1989 (Table 3). All indices of growth measured were higher in NT than in tilled plots (Table 3). Crown and fern weights and the number of bud clusters, buds, and ferns were higher by $178 \%, 175 \%, 152 \%, 161 \%$, and $195 \%$, respectively, in NT than in tilled plots. The metribuzin + napropamide combination did not reduce fern fresh weight but significantly reduced the number of bud clusters, buds, and ferns when compared to metribuzin alone. There was a significant interaction between herbicides and tillage on crown and fern weights (data not shown). Although crown and fern weights were higher in NT than in tilled plots, regardless of herbicide, in tilled treatments, metribuzin + napropamide decreased both crown and fern weights compared to metribuzin alone. In NT plots, metribuzin + napropamide increased crown and fern weights compared to metribuzin alone. Due to the significant harvest date $\times$ herbicide and harvest date $\mathrm{x}$ tillage interactions on all growth characteristics, data for each harvest date was analyzed separately.

Tillage treatments significantly affected total crown fresh weight throughout the 1989 growing season. At all harvest dates, NT led to a higher crown fresh weight than tillage (Fig. 1A). The total number of bud clusters and buds varied greatly over the season (Fig. $1 \mathrm{~B}$ and $\mathrm{C}$ ), but tillage generally reduced the number of buds and bud clusters. Counts for bud clusters and buds were high on 15 June in the NT treatment and decreased sharply at the following harvest (Fig. $1 \mathrm{~B}$ and C). The number of buds increased from July to September in all plots but decreased in NT plots from September to November. The numbers of bud clusters and buds were extremely variable in the metribuzintreated plots during the 1989 growing season and followed no distinct pattern (Fig. 2 A and B).

The number of ferns per plant and their fresh weight increased from May to September and decreased thereafter (Fig. $1 \mathrm{D}$ and

Table 1. Effect of tillage on total number and weight of marketable asparagus spears, $1985-89$.

\begin{tabular}{|c|c|c|c|c|c|c|c|c|c|c|}
\hline \multirow[b]{3}{*}{ Treatment } & \multicolumn{10}{|c|}{ Marketable spears } \\
\hline & \multicolumn{5}{|c|}{ No./ha $(\times 1000)$} & \multicolumn{5}{|c|}{ Wt $\left(\mathrm{kg} \cdot \mathrm{ha}^{-1}\right)$} \\
\hline & 1985 & 1986 & 1987 & 1988 & 1989 & 1985 & 1986 & 1987 & 1988 & 1989 \\
\hline Till & 33.5 & 52.9 & 75.5 & 92.9 & 92.2 & 781 & 1250 & 1460 & 1676 & 1753 \\
\hline NT & 37.4 & 81.3 & 133.5 & 139.3 & 178.0 & 883 & 1939 & 2950 & 2700 & 3390 \\
\hline Significance & NS & $* *$ & $* *$ & $* *$ & $* *$ & NS & $* *$ & $* *$ & $* *$ & $* *$ \\
\hline
\end{tabular}


Table 2. Effects of tillage on size distribution and percentage of marketable asparagus spears throughout the harvest season, 1989.

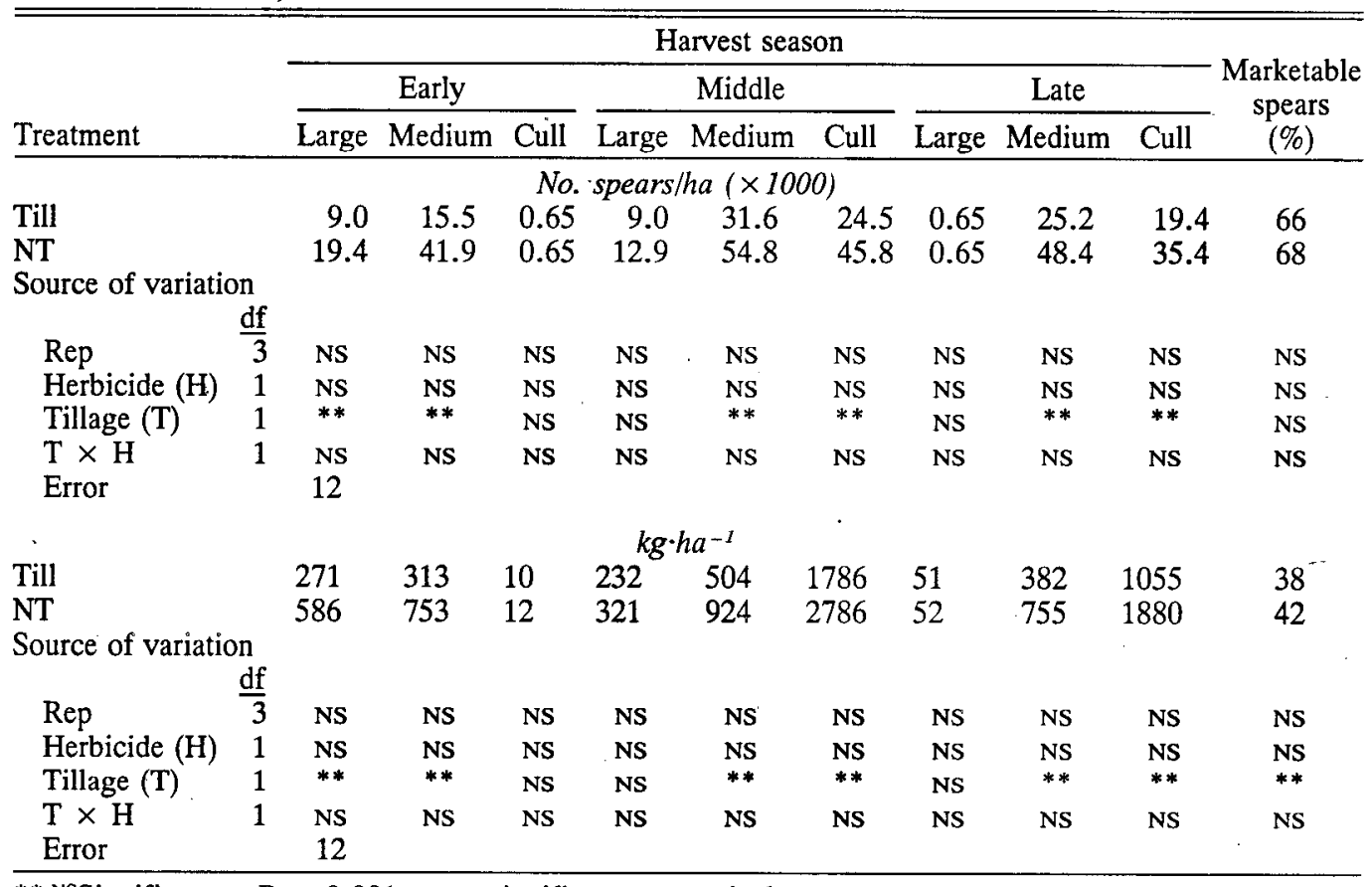

**,NsSignificant at $P=0.001$ or nonsignificant. respectivelv.

Table 3. Crown fresh weight; number of bud clusters, buds, and ferns; and fern fresh weight of asparagus as influenced by herbicide and tillage system.

\begin{tabular}{|c|c|c|c|c|c|c|}
\hline \multirow[b]{3}{*}{ Treatment } & & \multicolumn{5}{|c|}{ Growth characteristics (per plant) } \\
\hline & & \multirow{2}{*}{$\begin{array}{l}\text { Crown wt } \\
(\times 1000 \mathrm{~g})\end{array}$} & Bud clusters & Buds & Fern $^{x}$ & Fern $^{\mathbf{z}}$ \\
\hline & & & \multicolumn{3}{|c|}{ (no.) } & (g) \\
\hline Metribuzin & & 11.1 & 38.3 & 131.5 & 24.8 & 1447 \\
\hline Metribuzin + napropamide & & 11.2 & 27.8 & 97.0 & 20.3 & 1426 \\
\hline Tilled & & 8.0 & 26.2 & 87.6 & 15.1 & 1041 \\
\hline NT & & 14.3 & 39.9 & 140.7 & 29.4 & 1818 \\
\hline \multirow{2}{*}{\multicolumn{7}{|c|}{ Source of variation }} \\
\hline & & & & & & \\
\hline Rep & 3 & NS & NS & NS & NS & NS \\
\hline Herbicides $(\mathrm{H})$ & 1 & NS & $* * *$ & $* * *$ & NS & NS \\
\hline Harvest date (Hv) & 5 & $* * *$ & $* * *$ & *** & $* * *$ & $* * *$ \\
\hline $\mathrm{H} \times \mathrm{Hv}$ & 5 & NS & $* * *$ & $* * *$ & ** & $*$ \\
\hline Tillage (T) & 1 & $* *$ & $* * *$ & $* * *$ & $* * *$ & $*$ \\
\hline $\mathrm{H} \times \mathrm{T}$ & 1 & $*$ & NS & NS & NS & * \\
\hline $\mathrm{Hv} \times \mathrm{T}$ & 5 & NS & NS & NS & $*$ & $* *$ \\
\hline $\mathbf{H} \times \mathbf{H v} \times \mathrm{T}$ & 5 & NS & NS & NS & NS & NS \\
\hline Error & 69 & & & & & \\
\hline
\end{tabular}

${ }^{2}$ Analysis excludes first four harvest dates before fern development (degrees of freedom for harvest $=3$ and error $=44$ ).

$*, * * * * *$, Ns Significant at $P=0.05,0.01$, and 0.001 or nonsignificant, respectively.

E). Both the number and weight of ferns were higher in NT than in tilled treatments over the fern growing period (July to September).

Herbicide treatments apparently had more impact on the number of bud clusters and buds than on fern count or weight (Fig. 2 ). Bud cluster and bud counts in metribuzin + napropamidetreated plots were constant during the harvest season and increased during the fern growth period before declining late in the year. There were significantly more buds and bud clusters in the metribuzin than in the metribuzin + napropamide-treated plots early in the season. Changes in fern count and weight were similar for the different herbicide combinations (Fig. $2 \mathrm{C}$ and D). Both the number and weight of ferns increased rapidly after the completion of the harvest to a maximum in September before declining late in the year.

Storage carbohydrate levels decreased gradually in the NT plots but were relatively stable in the tilled plots during the spring harvest period (April to June) (Fig. IF). After the completion of the harvest period, carbohydrate levels declined sharply in all plots, especially tilled plots, as shoots were produced, reaching minimum values in August. Carbohydrate levels increased rapidly and returned to preharvest values by late Sep- 

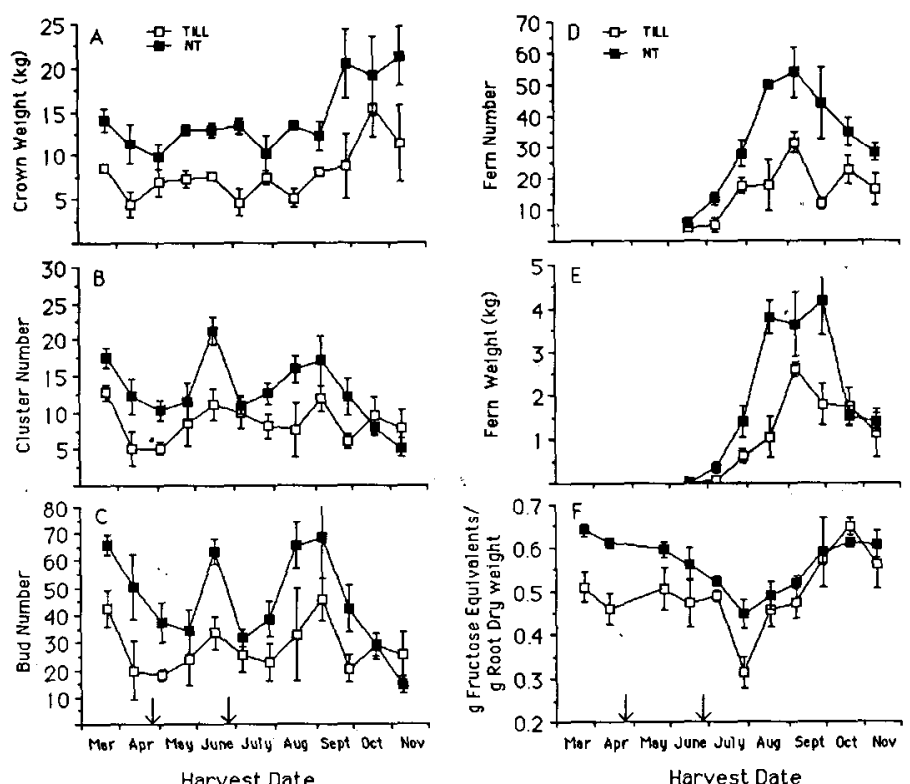

Fig. 1. Effect of tillage treatments on asparagus crown weight (A), cluster count (B), bud count (C), fern count (D), fern weight (E), and root soluble carbohydrates (F) during the 1989 growing season. Arrows indicate the beginning and end of the harvest period. Data points are means of four replications \pm SE.

tember. In NT plots, storage carbohydrate content generally was higher than in tilled plots during the spring harvest and fern production periods (March to July) (Fig. IF). There were no significant differences in fructose equivalent levels between tillage treatments from August to the end of the sampling period.

\section{Discussion}

Yield reductions associated with tillage coincided with a reduced number of spears harvested each year in tilled, compared to NT, plots. Fewer spears were initiated in tilled plots, presumably because of the smaller crowns, fewer buds and bud clusters, and lower root carbohydrate levels observed in 1989 at the beginning of the harvest season (Fig. 1) in tilled compared to NT plots. The effect of tillage on yield is apparent throughout the entire harvest season, and not just on early yield when the impact of spring tillage would be expected to be most dramatic. Visual observations of the crowns grown in tilled plots revealed some damage to the rhizome by the rototiller. In addition, spear and/or bud damage by postharvest tillage delayed fern establishment and reduced both the number and weight of ferns throughout the season. The apparent lack of difference in fern dry weights between tilled and NT plots late in the season is probably due to natural senescence and abscission of biomass that would mask treatment differences late in the season (Fig. $1 \mathrm{D}$ and $\mathrm{E})$. This result is consistent with observations made by Putnam (1972) on fern vigor following tillage. He reported that fern growth late in the season in NT plots appeared taller and more vigorous than in tilled plots when a postharvest tillage operation had been performed. In addition, fern count decreases late in the season, as shown in Fig. 2, maybe a result of natural senescence of fern over a growing season and/or due to mechanical damage resulting from repeated use of a tractor in plots during root harvests.

Although tillage reduced crown size, the patterns of crown growth in this study were similar in tilled and NT plots. Crown fresh weights remained relatively stable (Fig. 1A) during the

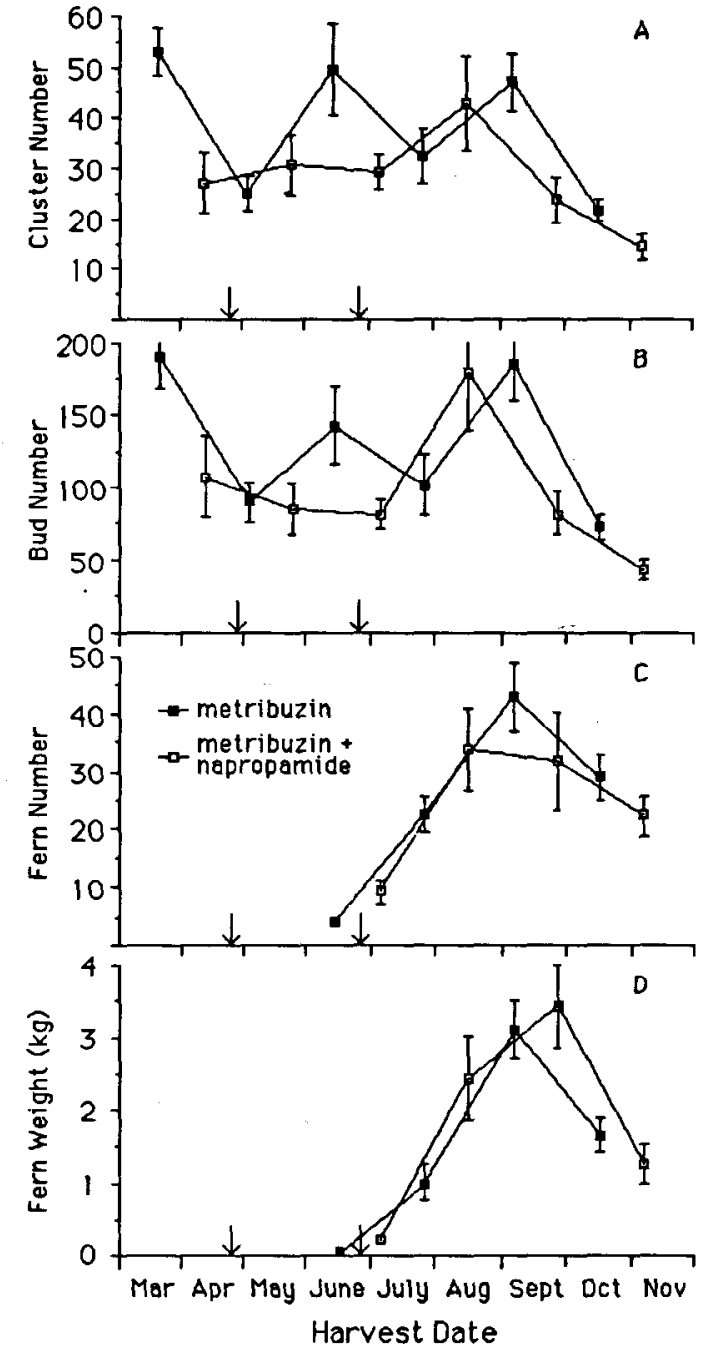

Fig. 2. Influence of herbicide treatment on asparagus cluster (A), bud (B), and fern counts (C), and fern weight (D) during the 1989 growing season. Arrows indicate the beginning and end of the harvest period. Data points are the means of eight replications (two tillage treatments and four replications) \pm SE.

1989 growing season and increased in September when fern growth ceased. Crown weight increases late in the season were apparently due to the translocation of carbohydrates into the roots from senescing shoots (Fig. IE), as reported previously by Fisher (1982). In contrast, Haynes (1987) noted that crown weight continued to increase over the entire growing season in young plants. It is possible that a combination of natural root senescence, regional areas of die-back in the crown, and depletion of carbohydrates by harvest result in maintenance of a relatively constant crown weight throughout the year in older plants compared to young plants that are growing vigorously and not yet being harvested. Maintenance of a relatively constant crown weight from year to year is most likely related to the yield stability observed in mature asparagus plantings.

Cluster and bud counts varied greatly throughout the year (Fig. 1 B and C). However, counting buds on large, freshly excavated roots was difficult and may account for the large standard errors associated with these data. Bud counts declined early in the season because of the initiation of harvest and possibly because of natural senescence/decay in cold, wet spring soils. As the harvest period progressed, small buds began to 
enlarge, which facilitated counting and may account for the apparent increase in the number of buds as the harvest season progressed. In addition, release of apical dominance resulting from spear harvest would cause dormant buds to enlarge and grow, which would further facilitate counting. This change may have been especially true of the vigorous and healthy crowns in the NT treatment and may account for the apparent outlying point in bud counts in NT plots in mid-June. After fern establishment, buds were steadily initiated until the time of peak fern production (August and September) in a manner similar to that observed in young asparagus plants (Fisher, 1982; Haynes, 1987). Late in the season, bud and bud cluster counts again declined as plants became dormant and overwintering scales developed, complicating counting.

Root carbohydrate levels were similar to those reported elsewhere for asparagus (Haynes, 1987; Shelton and Lacy, 1980). Carbohydrate levels declined gradually during the harvest period and were reduced sharply during postharvest fern production. Carbohydrate levels increased rapidly after fern maturity and achieved preharvest values by late September. Higher carbohydrate levels in the roots of NT than tilled plots would mean more stored reserve available for spear growth during harvest and would contribute, along with the higher bud counts, to the higher yields in NT than in tilled plots. Although carbohydrate contents were significantly lower in tilled than in NT plots at the beginning of the season (March), they were similar in all plots by November. One would expect the differences observed in December to be evident the following spring. However, the 1989 growing season was very wet compared to the very dry season in 1988. Even though plots were irrigated, moisture stress in the 1988 season may have inhibited carbohydrate accumulation more in plants in tilled than in NT plots because of less vigorous growth in the former. Thus, carbohydrate levels may have been significantly different between till and NT treatments at the start of 1989 because of stress experienced during the previous growing season.
No significant yield reductions were noted with the use of metriuzin + napromide, but reduced growth and the trend toward reduced yields in tilled plots with metrizin and naropamide suggests a possible phyotoxic effect (Table 3; Fig. 2 A and $\mathrm{B})$. The significant herbicide $\times$ tillge interaction on crown and fern weights suggests that applications of naopamide may limit the growth of asparagus crowns under tilled conditions. There were significantly fewer bud clusters and buds with mtribuin + naprpamide than with metibuzin alone, which suggests that the addition of naprpamide may be phytooxic. The extreme variation in cluster and bud counts between the harvest dates for the metibuzin-treated plots makes comparison to the metribzin + naproamide treatment difficult. This apparent phytooxicity may be limited to the developing buds, as fern count and fresh weight were similar for the herbicides.

\section{Literature Cited}

Benson, B.L. and F.H. Takatori. 1980. Partitioning of dry matter in open-pollinated and $F_{1}$ hybrid cultivars of asparagus. J. Amer. Soc. Hort. Sci. 105:567-570.

Dufault, R.J. and J.K. Greig. 1983. Dynamic growth characteristics in seedling asparagus. J. Amer. Soc. Hort. Sci. 108:1026-1030.

Fisher, K.J. 1982. Comparisons of growth and development of young asparagus plants established from seedling transplants and by direct seeding. New Zealand J. Expt. Agr. 10:405-408.

Haynes, R.J. 1987. Accumulation of dry matter and changes in storage carbohydrates and amino acid content in the first 2 years of asparagus growth. Scientia Hort. 32:17-23.

Putnam, A.R. 1972. Efficacy of a zero-tillage cultural system for asparagus produced from seeds and crowns. J. Amer. Soc. Hort. Sci. 97:621-624.

SAS Institute. 1985. SAS user's guide: Statistics. 1985 ed. SAS Institute, Inc., Cary, N.C.

Shelton, D.L. and M.L. Lacy. 1980. Effects of harvest duration on yield and depletion of storage carbohydrates in asparagus roots. J. Amer. Soc. Hort. Sci. 105:332-335. 